Abstract

\title{
Why don't we look to the west?
}

\author{
Harry Widianto and Sofwan Noerwidi
}

National Research Center of Archaeology, Yogyakarta Sub-Center

\begin{abstract}
Paleontological data indicate that the beginning of Java Island's human habitation took place at the Plio-Pleistocene boundary, around 2.4 Ma, along with uplift process and glacial-interglacial cycles. However, the oldest Homo erectus fossil was mainly found in the eastern part of Java Island where age-dating indicates that they were from ca. 1.5 Ma, especially along the riverbanks of Bengawan Solo and Brantas, such as Perning, Sangiran, Kedungbrubus, Ngandong, Ngawi, Trinil, and Sambungmacan.
\end{abstract}

Recently, Pleistocene sites were discovered from the western part of Java, e.g., Rancah (Ciamis), Semedo (Tegal), and Bumiayu (Brebes) with their archaeological, paleontological, and paleoanthropological potentials. This work will present the significance of the potential, especially paleoanthropological data from the new sites, and their implications to the Quaternary prehistory research strategies determination in the future.

We present new geological, archaeological, paleontological, and paleoanthropological evidence from those mentioned sites. The result shows that the distribution of Homo erectus were extended to the western part of Java, between 1.8-1.7 Ma, older than the oldest previous finding of Homo erectus from Perning and Sangiran. This finding suggests a new window of the human arrival on this island. So, why don't we look to the west? Intensive research in the future should be addressed to the western part of Java Island.

Keywords: Homo erectus, Plio-Pleistocene, Quaternary, Java

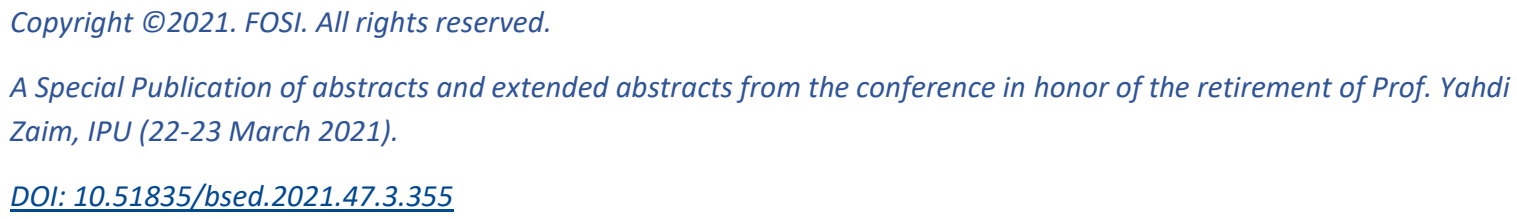

